\title{
Peningkatan Daya Saing UMKM Alas Kaki di Kecamatan Ciomas, Kabupaten Bogor dan Implikasinya terhadap Strategi Pemasaran
}

\author{
Ayatusyifa Nurzamzami \\ Departemen Manajemen, Fakultas Ekonomi dan Manajemen \\ Institut Pertanian Bogor \\ Kampus Darmaga Bogor 16680 \\ Edward H. Siregar \\ Departemen Manajemen, Fakultas Ekonomi dan Manajemen \\ Institut Pertanian Bogor \\ Kampus Darmaga Bogor 16680 \\ e-mail: edward.siregar@live.com
}

\begin{abstract}
Micro, Small and Medium Enterprises (MSMEs) footwear in Ciomas District, Bogor Region is one of the home industries in Bogor Region. The aim of this research is 1) to identify factors affecting the improvement of the product competitive ability; (2) to analyze the internal and external factors; and (3) to arrange strategies and make the strategy priorities to improve the MSMEs footwear competitive ability in Ciomas District. The results reveal that the strongest point to improve competitive ability is to create good and long-term relationship with both suppliers and customers (score 0.488), the main opportunity is the big market potential (score 0.534), and the main threat analysis is the competitors' more complete and innovative of products supported by the high technology (score 0.372). Furthermore the highest priority that can be chosen as the alternative strategy is to develop and enlarge markets by improving quality and product inovation (score 0.316).

Keywords: footwear, the competitive ability, and strategy.
\end{abstract}

\begin{abstract}
ABSTRAK
Usaha Mikro Kecil Menengah (UMKM) alas kaki di Kecamatan Ciomas, Kabupaten Bogor merupakan salah satu wilayah pengrajin home industry. Tujuan penelitian ini adalah : 1) Mengetahui faktor-faktor yang berpengaruh terhadap peningkatan daya saing produk; 2) Menganalisis faktor internal dan eksternal; dan (3) Menyusun strategi serta membuat prioritas strategi untuk meningkatkan daya saing UMKM alas kaki di Kecamatan Ciomas. Hasil analisis menunjukkan bahwa kekuatan utama untuk memiliki daya saing adalah memiliki hubungan jangka panjang yang baik dengan para pemasok dan pelanggan dengan skor 0.488 , potensi pasar yang cukup besar merupakan peluang utama dengan skor 0.534 , analisis ancaman utama adalah semakin lengkap dan inovatif desain fitur produk pesaing yang didukung teknologi canggih dengan skor 0.372. Alternatif strategi prioritas adalah strategi mengembangkan dan memperluas pasar dengan meningkatkan kualitas dan inovasi produk dengan bobot 0.316 .

Kata kunci : alas kaki, analisis daya saing, dan strategi.
\end{abstract}

\section{Pendahuluan}

Usaha Mikro Kecil Menengah (UMKM) alas kaki di Kecamatan Ciomas merupakan titik awal munculnya pengrajin sepatu sendal di Kabupaten Bogor. Daerah tersebut 
dijadikan sebagai salah satu sentra pembuatan alas kaki selain kecamatan Tamansari dan Dramaga. Menurut data Dinas Koperasi Usaha Kecil Menengah Perindustrian dan Perdagangan Kabupaten Bogor tahun 2012 terdapat sebelas desa pengrajin alas kaki di Kecamatan Ciomas, dengan total unit usaha sebanyak 901 unit dan jumlah tenaga kerja sebanyak 5617 orang. Pemerintah daerah (Pemda) memiliki tanggung jawab untuk berperan dalam mengembangkan industri didaerahnya, dan harus dapat menjamin terjadinya peningkatan produksi yang dilakukan dengan cara mengeluarkan kebijakan seperti penyediaan modal pinjaman, menciptakan iklim usaha yang kondusif, serta peningkatan peran kelembagaan koperasi yang mendukung.

Salah satu sektor industri manufaktur yang memilki prospek untuk tetap tumbuh dan berkembang adalah industri alas kaki. Industri alas kaki merupakan salah satu alternatif yang menjanjikan setelah pemerintah menggalakkan ekspor dalam sektor nonmigas dari berbagai komoditi. Menurut Kementerian Perindustrian (2012), perkembangan ekspor Indonesia pada tahun 2007-2011 berdasarkan sektor nonmigas (79.62\%) lebih besar dibandingkan sektor migas (20.38\%). Dilihat dari peran sub sektor industri terhadap ekspor sektor nonmigas, sektor industri (75.42\%) lebih besar dibandingkan sektor lainnya (24.58\%).

Tabel 1. Ekspor produk alas kaki Indonesia

\begin{tabular}{ccc}
\hline Tahun & Juta US \$ & Pertumbuhan (\%) \\
\hline 2005 & 1.43 & - \\
2006 & 1.6 & 12 \\
2007 & 1.64 & 2 \\
2008 & 1.88 & 15 \\
2009 & 1.74 & 7 \\
\hline Sumber: Diolah dari Statistik Ekspor-Impor, BPS dalam Majalah SWA (2010)
\end{tabular}

Badan Standardisasi Nasional mengemukakan bahwa faktor yang menjadi pendukung daya saing produk alas kaki nasional di antaranya adalah harga yang kompetitif, desain unik, tahan lama dan memiliki bahan yang eksotik dan bervariasi. Meningkatnya daya saing ini tentu meningkatkan pula permintaan akan produk alas kaki baik untuk memenuhi kebutuhan dalam negeri maupun untuk ekspor. Dengan keunggulan ini, tidak mengherankan apabila angka ekspor produk alas kaki nasional dapat terus bertahan.

Berdasarkan pemaparan di atas, maka masalah dalam penelitian ini, akan diurai dalam beberapa pertanyaan berikut : 1) Faktor-faktor apa saja yang menghambat daya saing produk UMKM alas kaki di Kecamatan Ciomas?; 2) Apa saja yang menjadi faktorfaktor internal dan eksternal yang mempengaruhi daya saing UMKM alas kaki di Kecamatan Ciomas?; 3) Bagaimana menyusun strategi dalam meningkatkan daya saing UMKM alas kaki di Kecamatan Ciomas? dan (4) Apakah prioritas strategi untuk meningkatkan daya saing UMKM alas kaki di Kecamatan Ciomas?

Penelitian ini bertujuan untuk : 1) Mengetahui faktor-faktor yang berpengaruh terhadap peningkatan daya saing produk UMKM alas kaki di Kecamatan Ciomas sehingga mampu berdayasaing dengan produk lainnya baik dari dalam maupun luar negeri; (2) Menganalisis faktor internal dan eksternal yang mempengaruhi daya saing UMKM alas kaki di Kecamatan Ciomas; dan 3) Menyusun strategi serta membuat 
prioritas strategi untuk meningkatkan daya saing UMKM alas kaki di Kecamatan Ciomas.

\section{Metode Penelitian}

Penelitian ini dilakukan di beberapa UMKM yang berlokasi di Kecamatan Ciomas, Kabupaten Bogor yang bergerak dalam bidang usaha alas kaki. Pemilihan lokasi dilakukan dengan pertimbangan bahwa Kecamatan Ciomas merupakan salah satu sentra UMKM kerajinan alas kaki di kota Bogor. Data yang digunakan adalah data primer dan data sekunder. Data primer diperoleh melalui wawancara dan pengisian kuesioner oleh responden. Selain itu juga dilakukan pengamatan langsung di lapangan untuk memperoleh informasi tambahan yang mendukung seperti mengetahui faktor daya saing, faktor internal dan eksternal. Data sekunder diperoleh melalui studi literatur (buku, jurnal dan artikel terkait topik penelitian), serta data laporan internal industri alas kaki.

Pengambilan sampel dilakukan dengan menggunakan salah satu metode non probability sampling, yaitu teknik purposive sampling pada bulan Januari-Maret 2013. Kriteria responden yang akan diteliti memiliki pengetahuan dan memiliki pengalaman tentang objek yang diteliti. Responden yang dipilih mewakili perusahaan yang dianggap memiliki pemahaman mendalam mengenai kondisi persaingan dan kondisi perusahan secara keseluruhan, seperti koordinator industri (1 orang), ketua koperasi (1 orang), pemasok ( 2 orang), pengrajin (4 orang), akademisi (1 orang) dan staff kecamatan di bidang perekonomian (1 orang).

Pengolahan dan analisis data pada penelitian ini menggunakan Porter's Diamond Model untuk mengidentifikasikan faktor keunggulan kompetitif UMKM alas kaki di Kecamatan Ciomas serta dengan menganalisis faktor lingkungan internal dan eksternal industri melalui analisis Strength-Weakness-Opportunity-Threat (SWOT). Kemudian untuk menyusun dan menetapkan strategi meningkatkan daya saing perusahan digunakan metode Analytic Hierarchy Process (AHP) dalam merumuskan strategi yang terbaik bagi industri kecil dan menengah di Kecamatan Ciomas. Pengolahan data yang dilakukan dengan menggunakan program Expert Choice dan Microsoft Excel 2007.

Potensi industri alas kaki yang cukup besar disadari bagi para pelaku UMKM. Konsekuensinya sampai saat ini sudah cukup banyak perusahaan maupun UMKM yang menggeluti usaha ini sehingga menimbulkan munculnya para pesaing yang bergerak di bidang alas kaki. Munculnya para pesaing seperti produk buatan Cibaduyut dan China, menuntut UMKM alas kaki di Kecamatan Ciomas dapat meningkatkan kualitas produknya agar memiliki keunggulan kompetitif di pasar. Untuk keberlanjutan usaha ini, UMKM alas kaki di Kecamatan Ciomas dipengaruhi oleh adanya pengembangan usaha alas kaki itu sendiri, yaitu karakteristik industri, karakteristik usaha, motivasi usaha pengrajin, kebijakan Pemda dan kerja sama dengan mitra. Skema kerangka pemikiran penelitian ini dapat dilihat pada Gambar 1. 


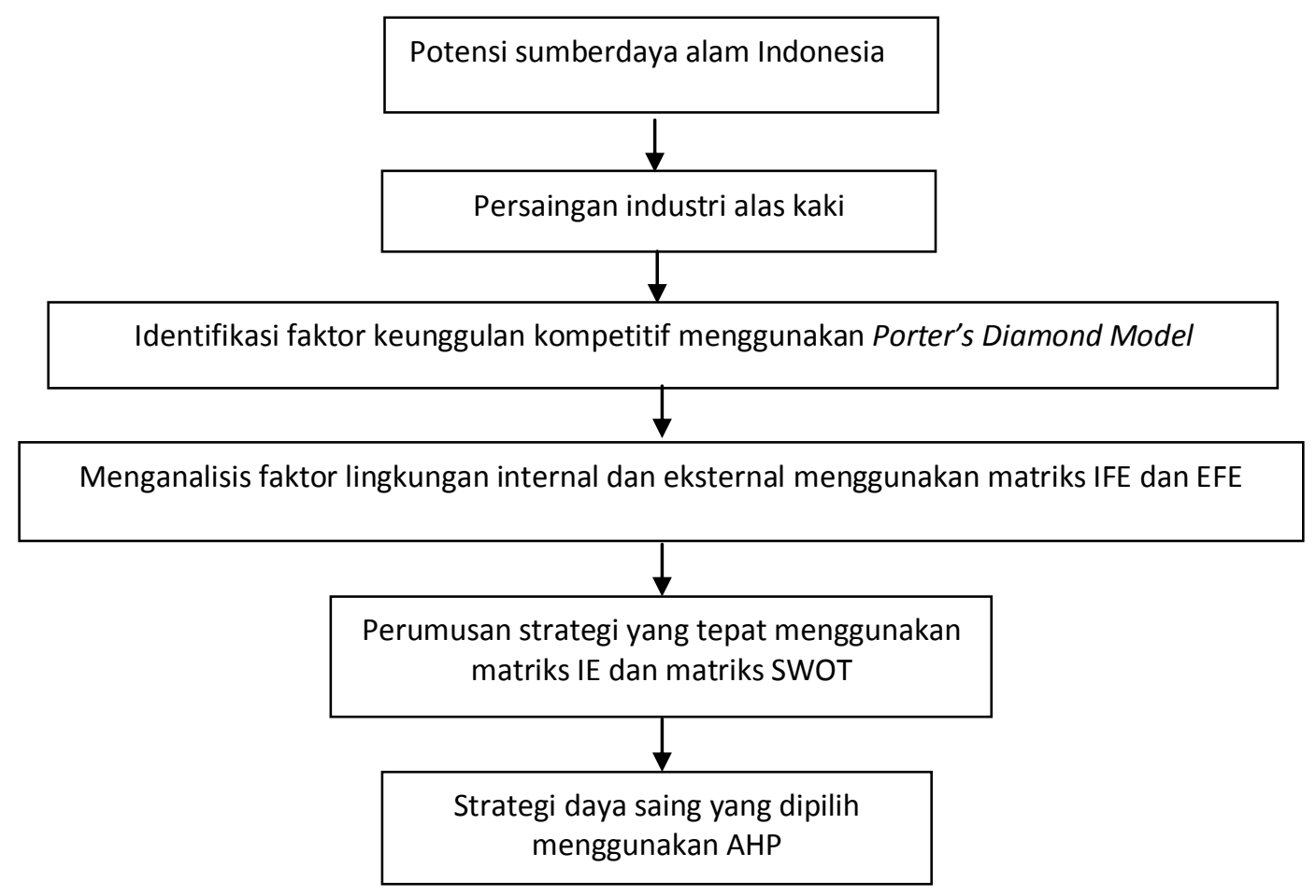

Gambar 1. Kerangka pemikiran penelitian

\section{Hasil dan Pembahasan}

III.1. Gambaran Umum UMKM Alas Kaki di Kecamatan Ciomas

UMKM alas kaki di Kecamatan Ciomas dapat dikelompokkan menjadi dua kelompok, yaitu UMKM pengrajin dan UMKM mandiri. Secara umum, UMKM pengrajin memiliki ketergantungan sepenuhnya pada pemberi order yang berkaitan dengan aspek permodalan, pangadaan bahan baku dan pemasaran. UMKM mandiri yang memiliki modal sendiri, tidak tergantung pada pemberi order. Keahlian membuat alas kaki yang dimiliki sebagian besar para pengrajin diperoleh secara turun-temurun serta dari pengalaman mereka, yang sebelumnya pernah bekerja sebagai buruh di bengkelbengkel alas kaki sehingga mereka sangat menguasai teknik-teknik dalam pembuatan alas kaki.

Berdasarkan organisasi, UMKM alas kaki di Kecamatan Ciomas tidak memiliki bentuk organisasi yang jelas dan terstruktur. Pemilik usaha menjabat sebagai pengawas, sementara pekerja lainnya bertugas pada bidang produksi, keuangan, pemasaran, dan penjualan yang telah memiliki keahlian tersebut. Pada posisi keuangan yang memegang peranan penting diberikan kepada orang yang telah dipercayai seperti sanak keluarga. Setiap pekerja saling berinteraksi dan bekerjasama dalam menyelesaikan pekerjaannya. Bentuk organisasi seperti ini dilakukan oleh pemilik usaha untuk meminimalisir pengeluaran gaji tenaga kerja, sehingga sulit untuk mengembangkan usaha ini.

Pada UMKM pengrajin, permasalahan utama yang dihadapi oleh pengrajin adalah permodalan (Sarma et al 2013). Keterbatasan permodalan membuat mereka melibatkan pemilik modal besar yang memperkenalkan sistem pembayaran dengan 
menggunakan 'bon putih'. Sistem bon putih adalah sistem kerjasama produksi antara pihak pengrajin alas kaki dan pihak pemberi order (grosir). Dalam sistem ini, grosir memberikan bon putih kepada pengrajin dengan cap atau identitas grosir, dimana tertulis bahan baku yang diperlukan dan jumlah order serta tempat pembelian bahan baku. Pengrajin memperlihatkan bon putih tersebut ke pemasok yang ditunjuk oleh pemberi order (grosir). Setelah pesanan selesai, dilakukan proses pengiriman barang. Pihak grosir akan memberikan sejumlah uang untuk membayar tenaga kerja, dengan memperhitungkan modal awal yang telah diambil melalui bon putih sisanya dibayar dengan giro berjangka (satu atau dua bulan) yang dapat ditukarkan dengan uang tunai, namun dikenakan potongan tertentu. Dengan adanya potongan serta rendahnya harga jual alas kaki menyebabkan kurang berkembangnya usaha ini.

Sementara UMKM mandiri, membeli bahan baku sendiri ke penjual bahan baku secara tunai maupun dengan sistem pembayaran berjangka. Hal ini dikarenakan modal UMKM mandiri berasal dari milik pribadi. Tapi ketersediannya modal UMKM mandiri juga terbatas, sehingga tidak dapat memenuhi permintaan pasar pada skala yang besar.

Dilihat dari segi kualitasnya, produk UMKM alas kaki di Kecamatan Ciomas memiliki kualitas baik dengan harga yang terjangkau (Sarma 2013). Para pengrajin tidak pernah mendesain model produk alas kaki sendiri, tapi mereka hanya menduplikasi produk alas kaki yang sedang tren di pasaran. Produk alas kaki yang dipasarkan diberi merek sesuai dengan merek pemasar atau pemberi order. Merek pemasar yang digunakan belum dipatenkan oleh pemberi order, yang digunakan sebagai pengenal sehingga pembeli dapat mengingatnya. Umumnya beberapa merek branded untuk segmen menengah ke atas yang dijual di mall-mall besar telah dipatenkan seperti Yongki Komaladi dan Bata. Hal ini membuktikan bahwa UMKM alas kaki di Kecamatan Ciomas sudah memiliki pengalaman dalam memproduksi sepatu yang bermutu dengan varian model yang disesuaikan dengan permintaan pasar.

\section{III.2. Analisis Faktor Daya Saing}

Pada penelitian ini faktor-faktor yang berpengaruh terhadap daya saing UMKM alas kaki di Kecamatan Ciomas diidentifikasi. Faktor-faktor tersebut dianalisis berdasarkan Porter's Diamond Model, seperti faktor kondisi, faktor kondisi permintaan, industri terkait dan industri pendukung, persaingan industri, peran pemerintah dan peran kesempatan (Porter 1990). Untuk mengetahui faktor yang paling berpengaruh terhadap peningkatan daya saing, maka aktor pengrajin, pemasok, pemerintah daerah, dan koperasi diambil sebagai responden, disamping beberapa kondisi dan dengan menggunakan skala 1-4 berdasarkan tingkat pengaruhnya terhadap daya saing UMKM alas kaki di Kecamatan Ciomas (Tabel 2).

Dari hasil analisis pada Tabel 2, dapat diketahui bahwa atribut yang memiliki nilai tertinggi adalah sumberdaya manusia, sumberdaya alam dan lingkungan, teknologi, preferensi konsumen, dan tingkat persaingan yang masing-masing bernilai 4.00. Sementara atribut yang memiliki nilai paling rendah adalah regulasi yang bernilai 2.50 . 
Tabel 2. Faktor yang berpengaruh terhadap daya saing UMKM alas kaki di Kecamatan Ciomas

\begin{tabular}{|c|c|c|c|c|c|c|c|}
\hline \multirow{2}{*}{ No. } & \multirow{2}{*}{ Atribut } & \multicolumn{4}{|c|}{ Nilai } & \multirow{2}{*}{ Responden } & \multirow{2}{*}{$\begin{array}{l}\text { Rata- } \\
\text { rata nilai }\end{array}$} \\
\hline & & 1 & 2 & 3 & 4 & & \\
\hline \multicolumn{8}{|c|}{ Faktor Kondisi } \\
\hline 1. & Sumberdaya manusia & - & - & - & 10 & 10 & 4.00 \\
\hline 2. & Sumberdaya modal & - & - & 3 & 7 & 10 & 3.70 \\
\hline 3. & Sumberdaya alam dan lingkungan & - & - & - & 10 & 10 & 4.00 \\
\hline 4. & Teknologi & - & - & - & 10 & 10 & 4.00 \\
\hline 5. & Infrastruktur & - & 2 & 6 & 2 & 10 & 3.00 \\
\hline \multicolumn{8}{|c|}{ Kondisi Permintaan } \\
\hline 6. & $\begin{array}{l}\text { Jumlah pembeli dan tingkat } \\
\text { pertumbuhan }\end{array}$ & - & - & 4 & 6 & 10 & 3.60 \\
\hline 7. & Preferensi konsumen & - & - & - & 10 & 10 & 4.00 \\
\hline \multicolumn{8}{|c|}{ Industri Terkait dan Industri Pendukung } \\
\hline 8. & Pemasok & - & 2 & - & 8 & 10 & 3.60 \\
\hline 9. & Pengrajin alas kaki & - & 2 & 5 & 3 & 10 & 3.10 \\
\hline \multicolumn{8}{|c|}{ Persaingan Industri } \\
\hline 10. & Tingkat persaingan industri alas kaki & - & - & - & 10 & 10 & 4.00 \\
\hline 11. & Strategi bersaing & - & 2 & 6 & 2 & 10 & 3.00 \\
\hline \multicolumn{8}{|c|}{ Peran Pemerintah } \\
\hline 12. & Regulasi & - & 5 & 5 & & 10 & 2.50 \\
\hline \multicolumn{8}{|c|}{ Peran Kesempatan } \\
\hline 13. & Iklim bisnis & - & 2 & 5 & 3 & 10 & 3.10 \\
\hline
\end{tabular}

Keterangan :

Nilai 4 = Sangat menentukan

Nilai 3 = Menentukan

Nilai 2 = Sedikit menentukan

Nilai 1 = Tidak menentukan

Sumber: Data diolah (2013)

\section{III.3. Tahapan Pengambilan Strategi}

Tahapan pengambilan strategi pada penelitian ini terdiri dari empat tahapan, yaitu :

\section{Internal Factor Evaluation Matrix (Matriks IFE)}

Analisis terhadap kondisi lingkungan internal UMKM alas kaki di Kecamatan Ciomas melalui aspek fungsional yang meliputi aspek keuangan, pemasaran, operasional, dan sumberdaya manusia sehingga menghasilkan beberapa faktor yang menjadi kekuatan dan kelemahan (David 2009). Suatu faktor internal disebut sebagai kekuatan apabila menyediakan keunggulan kompetitif bagi UMKM dan disebut kelemahan apabila terdapat sesuatu yang tidak dilakukan dengan baik oleh UMKM atau UMKM tidak memiliki kapasitas untuk melakukannya sementara pesaing telah memiliki kapasitas tersebut. Faktor-faktor internal dianalisis dengan menggunakan matriks IFE. Hasil dari matriks IFE UMKM alas kaki di Kecamatan Ciomas dapat dilihat pada Tabel 3.

Tabel 3. Matriks IFE UMKM alas kaki di Kecamatan Ciomas

\begin{tabular}{clccc}
\hline No & \multicolumn{1}{c}{ Faktor } & Bobot & $\begin{array}{c}\text { Rataan } \\
\text { Skor }\end{array}$ & $\begin{array}{c}\text { Skor } \\
\text { Terbobot }\end{array}$ \\
\hline & Kekuatan & & & \\
1 & Harga produk yang kompetitif dan terjangkau & 0.052 & 3.200 & 0.166 \\
2 & Didukung oleh pengrajin yang berpengalaman & 0.118 & 3.700 & 0.437 \\
\hline
\end{tabular}


Lanjutan Tabel 3

\begin{tabular}{|c|c|c|c|c|}
\hline No & Faktor & Bobot & $\begin{array}{l}\text { Rataan } \\
\text { Skor }\end{array}$ & $\begin{array}{c}\text { Skor } \\
\text { Terbobot }\end{array}$ \\
\hline 3 & $\begin{array}{l}\text { Memiliki hubungan yang erat antara pemilik usaha dan } \\
\text { pekerja }\end{array}$ & 0.125 & 3.900 & 0.488 \\
\hline 4 & $\begin{array}{l}\text { Desain unik dan bervariasi yang dapat memenuhi selera } \\
\text { konsumen }\end{array}$ & 0.049 & 3.300 & 0.162 \\
\hline 5 & Kemudahan memperoleh bahan baku & 0.101 & 3.700 & 0.374 \\
\hline \multirow[t]{2}{*}{6} & Citra roduk yang dikenal baik oleh masyarakat & 0.080 & 3.500 & 0.280 \\
\hline & Kelemahan & & & \\
\hline 1 & $\begin{array}{l}\text { Kurangnya fasilitas peralatan dan teknologi yang } \\
\text { mendukung }\end{array}$ & 0.099 & 1.200 & 0.119 \\
\hline 2 & Promosi yang belum efektif dan berkesinambungan & 0.050 & 1.600 & 0.080 \\
\hline 3 & $\begin{array}{l}\text { Pengawasan yang kurang terhadap hasil kerja produksi } \\
\text { dan mutu rendah }\end{array}$ & 0.055 & 1.600 & 0.088 \\
\hline 4 & Adanya ketergantungan modal pada pihak grosir & 0.141 & 1.100 & 0.155 \\
\hline 5 & Produksi sepatu berdasarkan pesanan & 0.089 & 1.300 & 0.116 \\
\hline \multirow[t]{2}{*}{6} & Sikap pengrajin tidak berani mengambil risiko & 0.042 & 1.700 & 0.071 \\
\hline & $\begin{array}{l}\text { Total } \\
\end{array}$ & 1.000 & & 2.535 \\
\hline
\end{tabular}

Sumber: Data diolah (2013)

Dari hasil perhitungan dapat diketahui bahwa faktor kekuatan UMKM alas kaki di Kecamatan Ciomas tertinggi adalah memiliki hubungan yang erat antara pemilik usaha dan pekerja (0.488). Sedangkan dari faktor kelemahan utama adalah adanya ketergantungan modal pada pihak grosir (0.155).

\section{External Factor Evaluation Matrix (Matriks EFE)}

Analisis terhadap kondisi lingkungan eksternal UMKM alas kaki di Kecamatan Ciomas meliputi lingkungan jauh dan lingkungan industri. Analisis menghasilkan beberapa faktor yang menjadi peluang dan ancaman. Peluang adalah situasi yang diinginkan atau disukai UMKM, sedangkan ancaman adalah penghalang bagi posisi yang diharapkan UMKM dan merupakan situasi yang tidak disukai dalam lingkungan UMKM. Faktor-faktor eksternal dianalisis dengan menggunakan matriks. Hasil dari matriks EFE UMKM alas kaki di Kecamatan Ciomas dapat dilihat pada Tabel 4.

Dari hasil perhitungan skor terbobot, dapat diketahui bahwa faktor peluang UMKM alas kaki di Kecamatan Ciomas adalah potensi pasar yang cukup besar (0.534). Dari faktor ancaman utama adalah semakin lengkap dan inovatif desain fitur produk pesaing yang didukung teknologi canggih (0.372).

Tabel 4. Matriks EFE UMKM alas kaki di Kecamatan Ciomas

\begin{tabular}{|c|c|c|c|c|}
\hline No & Faktor & Bobot & $\begin{array}{l}\text { Rataan } \\
\text { Skor }\end{array}$ & $\begin{array}{c}\text { Skor } \\
\text { Terbobot }\end{array}$ \\
\hline \multicolumn{5}{|c|}{$\begin{array}{l}\text { Peluang } \\
\end{array}$} \\
\hline 1 & $\begin{array}{l}\text { Memiliki hubungan jangka panjang yang baik dengan para } \\
\text { pemasok dan pelanggan }\end{array}$ & 0.109 & 3.400 & 0.371 \\
\hline 2 & Banyaknya tenaga kerja & 0.080 & 3.000 & 0.240 \\
\hline 3 & Potensi pasar yang cukup besar & 0.157 & 3.400 & 0.534 \\
\hline 4 & Teknologi yang berkembang & 0.038 & 2.100 & 0.080 \\
\hline 5 & Meningkatnya pertumbuhan pusat perbelanjaan atau mall & 0.052 & 3.000 & 0.156 \\
\hline 6 & $\begin{array}{l}\text { Tren gaya hidup masyarakat sehingga alas kaki menjadi barang } \\
\text { konsumsi utama atau primer }\end{array}$ & 0.104 & 3.400 & 0.354 \\
\hline
\end{tabular}


Lanjutan Tabel 4

\begin{tabular}{|c|c|c|c|c|}
\hline No & Faktor & Bobot & $\begin{array}{c}\text { Rataan } \\
\text { Skor }\end{array}$ & $\begin{array}{c}\text { Skor } \\
\text { Terbobot }\end{array}$ \\
\hline \multicolumn{5}{|c|}{ Ancaman } \\
\hline 1 & Semakin gencarnya promosi competitor & 0.058 & 2.600 & 0.151 \\
\hline 2 & $\begin{array}{l}\text { Semakin lengkap dan inovatif desain fitur produk pesaing } \\
\text { yang didukung teknologi canggih }\end{array}$ & 0.124 & 3.000 & 0.372 \\
\hline 3 & Situasi ekonomi yang tidak dapat diprediksi & 0.120 & 2.800 & 0.336 \\
\hline 4 & Infrastruktur yang masih kurang baik & 0.088 & 3.000 & 0.264 \\
\hline \multirow[t]{2}{*}{5} & Tingkat persaingan yang cukup tinggi dalam industri alas kaki & 0.071 & 2.600 & 0.185 \\
\hline & Total & 1.000 & & 3.041 \\
\hline
\end{tabular}

Sumber: Data diolah (2013)

\section{Internal-External Matrix (Matriks IE)}

David (2009) menjelaskan bahwa penggabungan matriks IFE dan matriks EFE akan menghasilkan matriks IE yang memosisikan berbagai divisi suatu organisasi dalam tampilan sembilan sel. Berdasarkan hasil yang didapat dari matriks IFE (2.535) dan matriks EFE (3.041), maka dapat digambarkan matriks IE sebagai berikut:

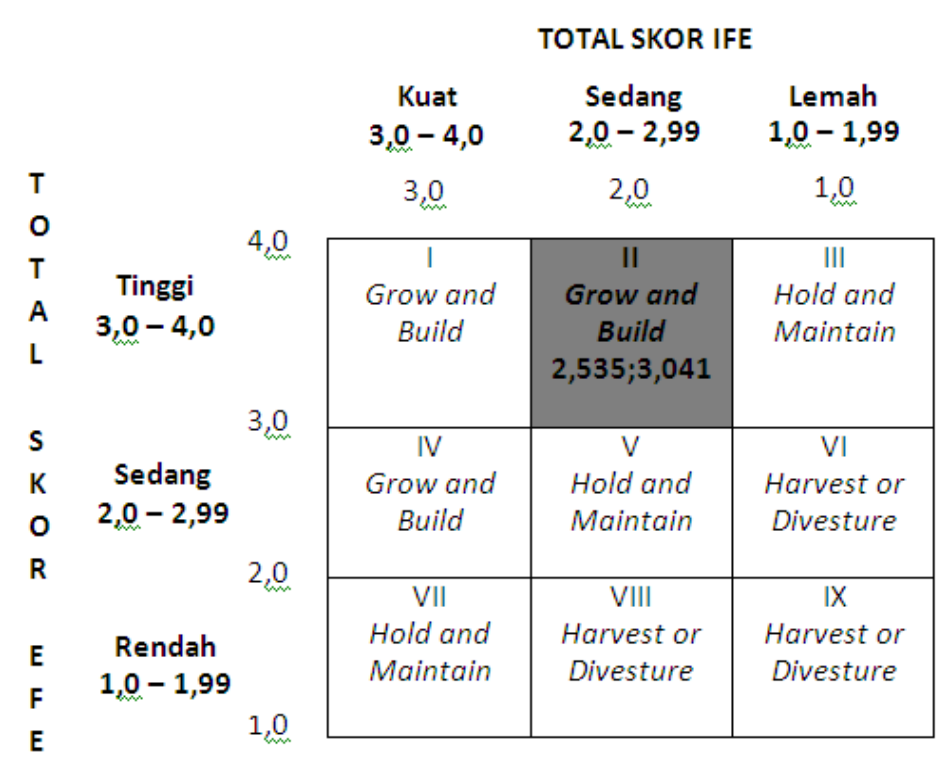

Gambar 2. Matriks IE UMKM alas kaki di Kecamatan Ciomas

Setelah nilai skor matriks IFE dan matriks EFE dicocokkan dengan matriks IE, terlihat posisi UMKM alas kaki di Kecamatan Ciomas berda pada sel II. Sel I, II, dan IV menggambarkan bahwa UMKM alas kaki berada pada daerah 'tumbuh dan membangun'. Pada daerah ini sebuah badan usaha harus menjalankan strategi intensif atau strategi integratif.Strategi intensif dapat berupa strategi penetrasi pasar, pengembangan pasar, dan pengembangan produk. Strategi integratif dapat berupa strategi integrasi ke belakang (melakukan akuisi terhadap pemasok), integrasi ke depan (melakukan akuisi terhadap distributor), dan integrasi horizontal (melakukan akuisi terhadap perusahaan pesaing yang sejenis). Posisi UMKM Ciomas hendaknya disesuaikan dengan tipe strategi yang dihasilkan pada matriks SWOT, yaitu strategi 
yang bersifat penetrasi pasar yang dapat dilakukan melalui pengembangan pasar atau pengembangan produk.

\section{Matriks SWOT}

Setelah melakukan identifikasi terhadap faktor-faktor internal yaitu dengan menggunalan matriks IFE dan matriks EFE, maka dapat dibuat matriks SWOT (lihat pada Gambar 3). Strategi yang ada pada matriks SWOT harus sesuai dengan strategi yang direkomendasikan pada matriks IE. Dengan menggunakan matriks SWOT, strategi yang dihasilkan terdiri atas strategi S-O (menggunakan kekuatan dengan memanfaatkan peluang yang ada), strategi W-O (mengatasi kelemahan dengan memanfaatkan peluang yang ada), strategi S-T (menggunakan kekuatan untuk menghindari ancaman), dan strategi W-T (meminimalkan kelemahan dan menghindari ancaman).

\begin{tabular}{|c|c|c|}
\hline EFE & $\begin{array}{l}\text { Kekuatan (S) } \\
\text { 1. Memiliki hubungan yang erat } \\
\text { antara pemilik usaha dan } \\
\text { pekerja } \\
\text { 2. Didukung oleh pengrajin yang } \\
\text { berpengalaman } \\
\text { 3. Kemudahan memperoleh } \\
\text { bahan baku }\end{array}$ & $\begin{array}{l}\text { Kelemahan (W) } \\
\text { 1. Sikap pengrajin tidak berani } \\
\text { mengambil risiko } \\
\text { 2. Promosi yang belum efektif } \\
\text { dan berkesinambungan } \\
\text { 3. Pengawasan yang kurang } \\
\text { terhadap hasil kerja } \\
\text { produksi dan mutu rendah }\end{array}$ \\
\hline $\begin{array}{l}\text { Peluang (0) } \\
\text { 1. Potensi pasar yang cukup } \\
\text { besar } \\
\text { 2. Memiliki hubungan jangka } \\
\text { panjang yang baik dengan } \\
\text { para pemasok dan } \\
\text { pelanggan }\end{array}$ & $\begin{array}{l}\text { Strategi S-O } \\
\text { 1. } \\
\text { Mengembangkan dan } \\
\text { memperluas pasar baru } \\
\text { dengan meningkatkan } \\
\text { kualitas dan inovasi produk } \\
\text { (S1, S2, S3, O1, O2) } \\
\text { 2. Fokus pada peningkatkan } \\
\text { kualitas bahan baku dan } \\
\text { peningkatan kuantitas produk } \\
\text { (S1, S2, S3, O1, O2) }\end{array}$ & $\begin{array}{l}\text { Strategi W-O } \\
\text { 1. } \text { Mengadakan pelatihan } \\
\text { motivasi, kewirausahaan, } \\
\text { dan peningkatan } \\
\text { (pengawasan) kinerja } \\
\text { manajemen mutu untuk } \\
\text { pengrajin (W1, W3, O1, O2) } \\
\text { 2. Memperluas pangsa pasar } \\
\text { di Indonesia dengan } \\
\text { memanfaatkan media } \\
\text { promosi (W2, O1,O2) }\end{array}$ \\
\hline $\begin{array}{l}\text { Ancaman (T) } \\
\text { 1. Semakin lengkap dan } \\
\text { inovatif desain fitur produk } \\
\text { pesaing yang didukung } \\
\text { teknologi canggih } \\
\text { 2. Situasi ekonomi yang tidak } \\
\text { dapat diprediksi }\end{array}$ & $\begin{array}{l}\text { Strategi S-T } \\
\text { 1. Membangun kerja sama } \\
\text { dengan stakeholder (pemasok } \\
\text { dan pesaing) untuk menjaga } \\
\text { kualitas dan memunculkan ciri } \\
\text { produk untuk mengantisipasi } \\
\text { persaingan usaha (S1, S2, S3, } \\
\mathrm{T} 1, \mathrm{~T} 2 \text { ) }\end{array}$ & $\begin{array}{l}\text { Strategi W-T } \\
\text { 1. Menggunakan teknologi } \\
\text { modern (desain) untuk } \\
\text { menghasilkan produk yang } \\
\text { inovatif dan bermutu } \\
\text { didukung dengan strategi } \\
\text { promosi yang efektif (W1, } \\
\text { W2, W3, T1, T2) }\end{array}$ \\
\hline
\end{tabular}

Gambar 3. Matriks SWOT UMKM alas kaki di Kecamatan Ciomas

\section{III.4. Analisis Pengambilan Keputusan Strategi}

Struktur AHP yang dapat membantu dalam pengambilan keputusan strategi UMKM alas kaki di Kecamatan Ciomas (Gambar 4) terdiri dari : 


\section{Faktor}

Faktor-faktor utama yang berpengaruh dalam penyusunan strategi peningkatan daya saing UMKM alas kaki di Kecamatan Ciomas, yaitu:
a. Persaingan Industri (F1)
b. Peran Kesempatan (F2)
c. Kondisi Permintaan (F3)
d. Industri Terkait dan Industri Pendukung (F4)
e. Faktor Kondisi (F5)

\section{Aktor}

Dalam kaitannya dengan implementasi strategi peningkatan daya saing UMKM alas kaki di Kecamatan Ciomas terdapat aktor-aktor yang berperan penting, yaitu :
a. Pengrajin (A1)
b. Pemasok (A2)
c. Pemerintah Daerah (A3)
d. Koperasi (A4)

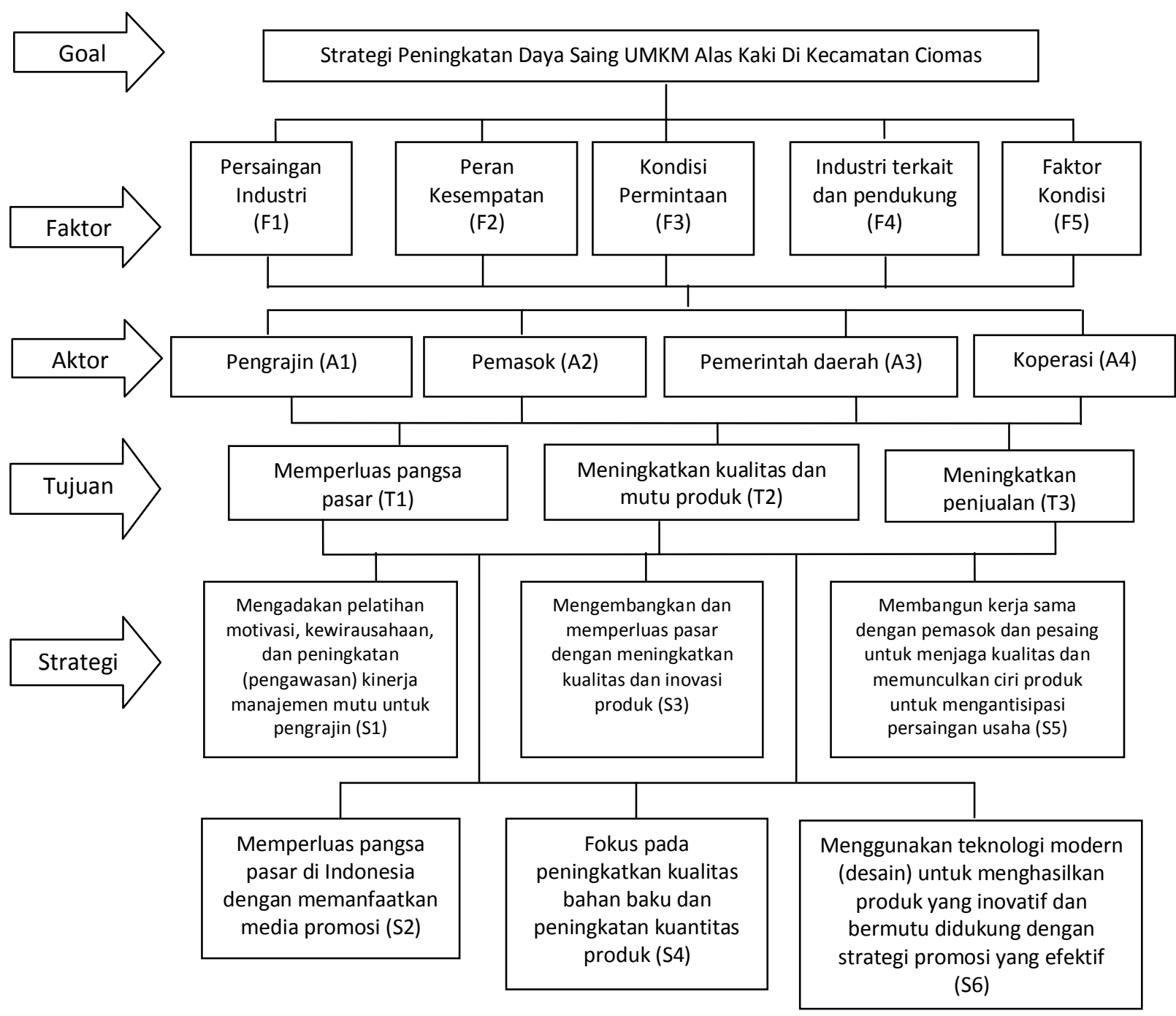

Gambar 4. Struktur AHP pada UMKM alas kaki di Kecamatan Ciomas 


\section{Tujuan}

Adapun tujuan yang ingin dicapai UMKM dalam kaitannya dengan keberhasilan strategi peningkatan daya saing UMKM alas kaki di Kecamatan Ciomas. Tujuan tersebut yaitu :
a. Memperluas Pangsa Pasar (T1)
b. Meningkatkan Kualitas Dan Mutu Produk (T2)
c. Meningkatkan Penjualan (T3)

\section{Alternatif Strategi}

Alternatif strategi yang dapat diambil berkaitan dengan strategi peningkatan daya saing UMKM alas kaki di Kecamatan Ciomas, yaitu:

a. Mengadakan pelatihan motivasi, kewirausahaan, dan peningkatan (pengawasan) kinerja manajemen mutu untuk pengrajin (S1)

b. Berusaha untuk memperluas pangsa pasar di Indonesia dengan memanfaatkan media promosi (S2)

c. Mengembangkan dan memperluas pasar baru merupakan hal mendesak untuk segera dilakukan melalui peningkatan kualitas dan inovasi produk (S3)

d. Berfokus pada peningkatkan kualitas bahan baku dan peningkatan kuantitas produk (S4)

e. Perlu membangun kerja sama dengan para pemangku kepentingan (stakeholders), yaitu pemasok untuk menjaga kualitas dan memunculkan ciri produk untuk mengantisipasi persaingan usaha (S5)

f. Penggunaan teknologi modern (dalam hal desain) untuk menghasilkan produk yang inovatif dan bermutu adalah hal mendesak untuk dilakukan dan didukung dengan strategi promosi yang efektif (S6).

\section{III.5. Interpretasi Hasil Pengolahan Data}

Pengolahan data menggunakan AHP dapat dilakukan melalui dua sudut pandang yaitu pengolahan horizontal dan pengolahan vertikal. Pengolahan horizontal menunjukkan besarnya tingkat pengaruh suatu unsur dengan unsur lainnya terhadap hierarki di atasnya. Pengolahan vertikal menunjukan pengaruh masing-masing unsur dalam suatu hierarki terhadap fokus utama. Identifikasi fokus utama, aktor yang berperan, faktor yang mempengaruhi, tujuan yang ingin dicapai dan alternatif strategi peningkatan daya saing dilakukan melalui observasi awal dan wawancara terstruktur dengan pihak internal UMKM.

\section{Pengolahan Vertikal}

\section{a. Faktor}

Hasil pengolahan vertikal pada tingkat faktor untuk pengambilan keputusan strategi peningkatan daya saing UMKM alas kaki di Kecamatan Ciomas (lihat pada Tabel 5). Berdasarkan Tabel 5, faktor yang menjadi prioritas utama untuk meningkatkan daya saing UMKM alas kaki di Kecamatan Ciomas adalah faktor kondisi (0.371). Karena dengan adanya SDM, SDA, modal, teknologi, dan infrastruktur yang mendukung para pengrajin dapat memilih kualitas bahan baku yang tinggi, tenaga kerja yang berkompeten, dan dapat membeli alat teknologi yang canggih, sehingga dapat berdayasaing dengan pesaing lain. Faktor kedua 
yang dapat meningkatkan daya saing UMKM alas kaki di Kecamatan Ciomas adalah kondisi permintaan (0.213). Faktor ini menjadi penting karena dalam melakukan kegiatan produksi dilakukan sesuai dengan jumlah permintaan produk alas kaki.

Tabel 5. Bobot faktor

\begin{tabular}{ccc}
\hline Faktor & Bobot & Prioritas \\
\hline F1 & 0.100 & 5 \\
F2 & 0.114 & 4 \\
F3 & 0.213 & 2 \\
F4 & 0.202 & 3 \\
F5 & 0.371 & 1 \\
\hline
\end{tabular}

Sumber: Data diolah (2013)

Selanjutnya faktor industri terkait dan pendukung (0.202) menjadi prioritas ketiga yang menjadi pertimbangan untuk meningkatkan daya saing UMKM alas kaki di Kecamatan Ciomas. Dengan adanya pemasok bahan baku dan industri pendukung lainnya dapat memajukan UMKM alas kaki sehingga menjadi unggul dalam perekonomian daerah. Di prioritas keempat, faktor peran kesempatan (0.114) menjadi nilai penting, untuk mengetahui sejauh mana industri dapat berkembang sesuai dengan iklim bisnis atau usahanya. Faktor yang paling kecil tingkat kepentingannya menurut responden adalah persaingan industri (0.100). Dimana struktur, strategi, dan persaingan industri alas kaki yang dapat menentukan industri tersebut dapat bersaing atau bertahan dengan strategi yang diterapkannya.

b. Aktor

Hasil pengolahan vertikal pada tingkat aktor untuk pengambilan keputusan strategi peningkatan daya saing UMKM alas kaki di Kecamatan Ciomas (lihat pada Tabel 6).

Tabel 6. Bobot aktor

\begin{tabular}{ccc}
\hline Aktor & Bobot & Prioritas \\
\hline A1 & 0.398 & 1 \\
A2 & 0.332 & 2 \\
A3 & 0.134 & 3 \\
A4 & 0.130 & 4 \\
\hline
\end{tabular}

Sumber: Data diolah (2013)

Aktor yang berperan penting dan memiliki prioritas utama dalam peningkatan daya saing UMKM alas kaki di Kecamatan Ciomas adalah pengrajin alas kaki (0.398). Dimana pengrajin yang membuat produk, sehingga dapat menentukan produk akhir alas kaki menjadi produk yang memiliki kualitas baik.Pemasok (0.332) merupakan aktor kedua yang berperan (prioritas kedua). Pemasok juga dapat mempengaruhi daya saing suatu produk, adanya berbagai macam kualitas bahan baku yang ditawarkan dan dengan harga yang beragam. 
Aktor yang menjadi peran ketiga (prioritas ketiga) adalah pemerintah daerah (0.134).Pemda juga berkontribusi untuk meningkatkan keunggulan komoditi daerah. Dengan cara menyediakan teknologi, dan melakukan proses pengawasan. Aktor yang terakhir dengan prioritas keempat adalah koperasi (0.130). Koperasi dapat memberikan bantuan modal dan memasarkan produk. Sehingga akan terlihat jumlah permintaan suatu industri dapat berdayasaing dengan industri yang sejenis.

c. Tujuan

Hasil pengolahan vertikal pada tingkat tujuan untuk pengambilan keputusan strategi peningkatan daya saing UMKM alas kaki di Kecamatan Ciomas (lihat pada Tabel 7).

Tabel 7. Bobot tujuan

\begin{tabular}{ccc}
\hline Tujuan & Bobot & Prioritas \\
\hline T1 & 0.282 & 2 \\
T2 & 0.451 & 1 \\
T3 & 0.261 & 3 \\
\hline
\end{tabular}

Sumber: Data diolah (2013)

Berdasarkan Tabel 7, tujuan utama yang ingin dicapai oleh UMKM alas kaki di Kecamatan Ciomas dalam penyusunan strategi peningkatan daya saing adalah meningkatkan kualitas dan mutu produk (0.451). Dengan meningkatnya kualitas dan mutu produk yang diberikan kepada konsumen, UMKM alas kaki di Kecamatan Ciomas mampu meningkatkan daya saing produknya. Sehingga dapat mengembangkan usaha menjadi luas. Selanjutnya, tujuan yang menjadi prioritas kedua adalah memperluas pangsa pasar (0.282). Hal ini membuktikan dengan meningkatnya kualitas dan mutu produk, maka pangsa pasar akan menjadi luas sehingga akan meningkatnya penjualan atau permintaan pasar. Meningkatnya penjualan (0.261) merupakan tujuan pada prioritas ketiga.

d. Strategi

Hasil pengolahan vertikal pada tingkat alternatif strategi untuk pengambilan keputusan strategi peningkatan daya saing UMKM alas kaki di Kecamatan Ciomas (Tabel 8).

Tabel 8. Bobot strategi

\begin{tabular}{ccc}
\hline Strategi & Bobot & Prioritas \\
\hline S1 & 0.059 & 6 \\
S2 & 0.071 & 5 \\
S3 & 0.316 & 1 \\
S4 & 0.271 & 2 \\
S5 & 0.176 & 3 \\
S6 & 0.107 & 4 \\
\hline
\end{tabular}

Sumber: Data diolah (2013)

Berdasarkan Tabel 8, alternatif strategi yang paling banyak dipilih oleh responden adalah alternatif strategi ketiga yaitu mengembangkan dan memperluas pasar baru dengan meningkatkan kualitas dan inovasi produk 
(0.316). Pengrajin dapat memperluas pasar di berbagai kota untuk mendapatkan pelanggan baru dengan memperhatikan kualitas dan inovasi produk. Alternatif strategi kedua yaitu fokus pada peningkatkan kualitas bahan baku dan peningkatan kuantitas produk (0.271). Dalam pembuatan proses produksi, pengrajin harus memperhatikan kualitas bahan baku yang digunakan serta melakukan peningkatan kuantitas produk karena potensi pasar yang cukup besar terhadap permintaan alas kaki. Strategi membangun kerja sama dengan stakeholder terkait untuk menjaga kualitas dan memunculkan ciri produk untuk mengantisipasi persaingan usaha (0.176) menempati prioritas ketiga. Membangun kerja sama dengan stakeholder terkait dapat berupa strategi promosi untuk peningkatan penjualan maupun perluasan pasar serta terjalinnya hubungan antara pengrajin dengan pemasok, pemda, dan pemberi order.

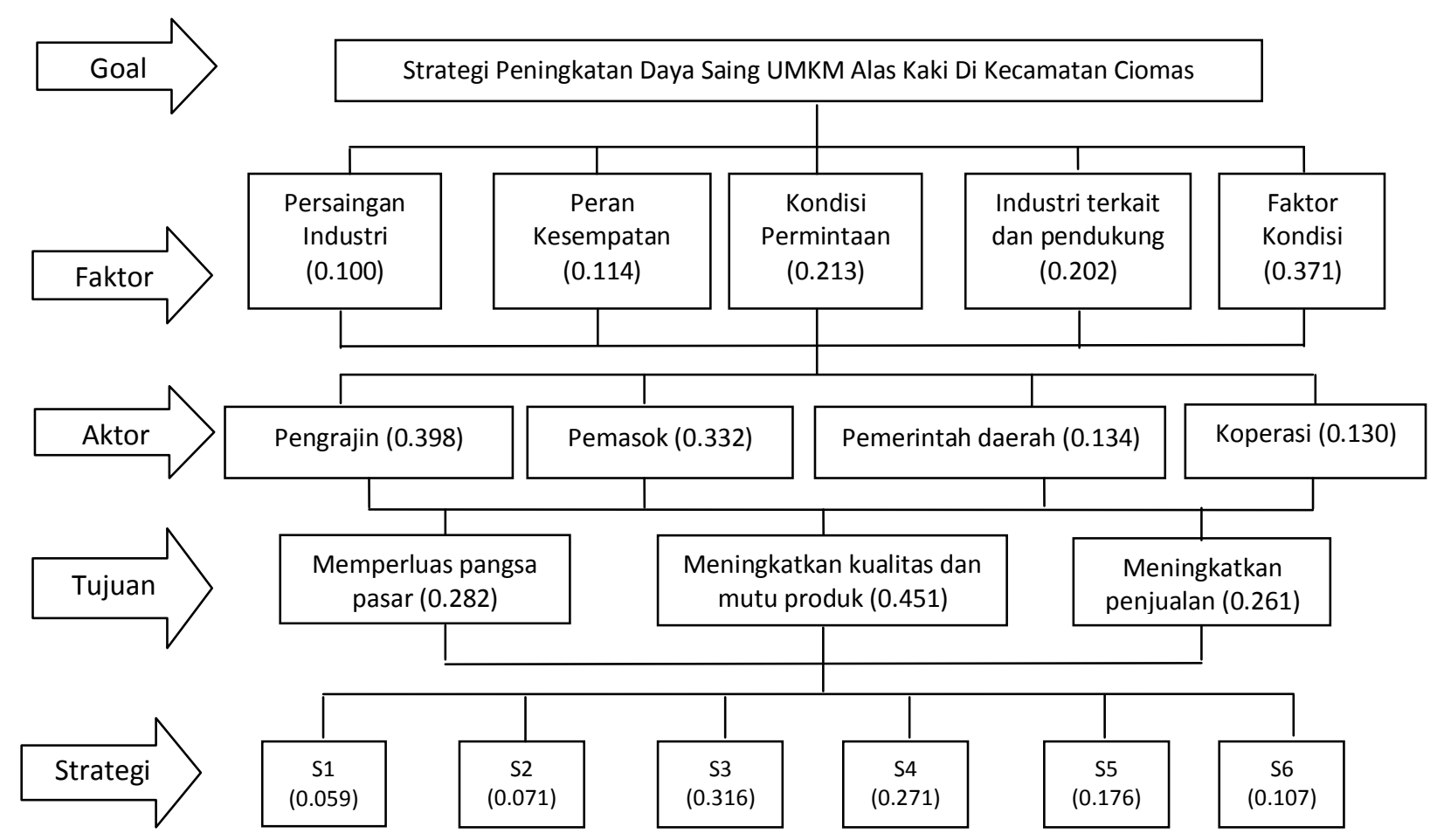

Gambar 5. Hasil analisis dalam struktur AHP pada UMKM alas kaki di Kecamatan Ciomas

Alternatif strategi ketiga yaitu menggunakan teknologi modern untuk menghasilkan produk yang inovatif dan bermutu didukung dengan strategi promosi yang efektif (0.107). Strategi ini dapat menyediakan produk dengan kualitas baik yang sesuai permintaan, mengurangi kesalahan maupun kecacatan dalam produksi, proses produksi dalam skala besar dan efisien. Alternatif strategi kelima yaitu memperluas pangsa pasar di Indonesia dengan memanfaatkan media promosi $(0.071)$ dan strategi yang terakhir yaitu mengadakan pelatihan motivasi, kewirausahaan, dan peningkatan kinerja manajemen mutu untuk pengrajin (0.059). 


\section{Kesimpulan}

Berdasarkan hasil penelitian yang telah dilakukan, dapat disimpulkan bahwa faktor-faktor yang paling berpengaruh terhadap peningkatan daya saing UMKM alas kaki di Kecamatan Ciomas adalah sumberdaya manusia, sumberdaya alam dan lingkungan, teknologi, preferensi konsumen, dan tingkat persaingan yang masingmasing bernilai 4.00. Kekuatan utama dari UMKM alas kaki di Kecamatan Ciomas adalah terciptanya hubungan jangka panjang yang baik dengan para pemasok dan pelanggan dengan skor 0.488 . Sedangkan kelemahan utama adanya ketergantungan modal pada pihak grosir dengan skor 0.155. Total skor dari kondisi internal sebesar 2.535 , yang menunjukan kondisi internal UMKM cukup kuat. Potensi pasar yang cukup besar merupakan peluang utama dengan skor 0.534 . Sedangkan ancaman utama adala semakin lengkap dan inovatifnya desain fitur produk pesaing yang didukung teknologi canggih dengan skor 0.372 . Total skor dari kondisi eksternal sebesar 3.041 yang berarti UMKM memiliki kemampuan yang baik dalam merespon faktor-faktor eksternal.

Rumusan strategi yang diberikan agar dapat meningkatkan daya saing UMKM alas kaki di Kecamatan Ciomas adalah mengadakan pelatihan motivasi, kewirausahaan, dan peningkatan kinerja manajemen mutu untuk pengrajin, memperluas pangsa pasar di Indonesia dengan memanfaatkan media promosi, mengembangkan dan memperluas pasar baru dengan meningkatkan kualitas dan inovasi produk, fokus pada peningkatan kualitas bahan baku dan peningkatan kuantitas produk, membangun kerja sama dengan berbagai mitra usaha untuk menjaga kualitas dan memunculkan ciri produk untuk mengantisipasi persaingan usaha. Selain itu perlu menggunakan teknologi modern untuk menghasilkan produk yang inovatif dan bermutu didukung dengan strategi promosi yang efektif. Prioritas strategi yang paling tinggi untuk dipilih agar dapat menigkatkan daya saing adalah strategi mengembangkan dan memperluas pasar baru dengan meningkatkan kualitas dan inovasi produk dengan bobot 0.316.

\section{Daftar Pustaka}

[BPS] Badan Pusat Statistik. 2010. Ekspor Produk Alas Kaki Indonesia. Majalah SWA, Ed 14:50, 27 Oktober 2010.

David FR. 2009. Manajemen Strategis: Konsep. Dono Sunardi, penerjemah. Ed ke-12. Jakarta (ID): Salemba Empat.

Kementerian Perindustrian. 2012. Perkembangan Ekspor Indonesia Berdasarkan Sektor pada Tahun 2007-2011; Pemantauan Ekspor Kelompok Hasil Industri Alas Kaki tahun 2008-2011; Pemantauan Impor dan Ekspor Kulit, Barang Kulit, dan Sepatu/Alas Kaki Tahun 2009-2011. [Internet. [diunduh 2012 Des 25]. [Tersedia pada : http://www.kemenperin.go.id/_jawaban.php?id=4042-08187.

Porter ME. 1990. The Competitive Advantage of Nations. New York (US): The Free Pass.

Sarma M, Septiani S, Dewi FR, Siregar EH. 2013. The Impact of Entrepreneurial Marketing and Business Development on Business Sustainability : Small and Household Footwear Industries in Indonesia. International Journal of Marketing Studies. 5(4): 110-122.doi:10.5539/ijms.v5n4p110.

Sarma M. 2013. Entrepreneurial Marketing. Untuk Keberhasilan Pemasaran bagi Usaha Mikro, Kecil, dan Menengah (UMKM) Indonesia. Bogor (ID): IPB Press. 